\title{
PAIN INTENSITY AND FUNCTIONALITY AFTER PERCUTANEOUS ENDOSCOPIC DISCECTOMY: A RETROSPECTIVE COHORT STUDY
}

\author{
INTENSIDADE DE DOR E FUNCIONALIDADE APÓS DISCECTOMIA ENDOSCÓPICA \\ PERCUTÂNEA: ESTUDO DE COORTE RETROSPECTIVO
}

\author{
INTENSIDAD DEL DOLOR Y FUNCIONALIDAD DESPUÉS DE LA DISCECTOMÍA \\ ENDOSCÓPICA PERCUTÁNEA: UN ESTUDIO DE COHORTE RETROSPECTIVO
}

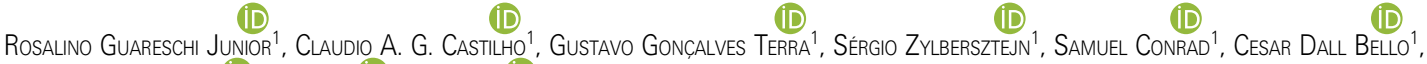 \\ Nilson Rodinel Rodrigues' ${ }^{1}$, Felipe Loss ${ }^{1}$, Yorito KISAKI ${ }^{1}$ \\ 1. Orthopedic Spine Surgery Service of the Complexo Hospitalar Santa Casa de Porto Alegre, Porto Alegre, RS, Brazil.
}

\begin{abstract}
Objectives: To evaluate pain intensity and functional status before and 30 days following percutaneous lumbar endoscopic discectomy. Methods: A retrospective cohort study that included patients who underwent percutaneous endoscopic discectomy from January 2019 to October 2020 at the Irmandade Santa Casa de Misericórdia Hospital, in Porto Alegre. The data were collected from the electronic medical records of the patients by two independent physicians. Clinical outcomes were assessed using visual analog scale (VAS) and Oswestry Disability Index (ODI) scores. Results: Forty-six patients with a mean age of $52.6 \pm 15.8$ years, 27 of whom (58.7\%) were male, were evaluated. Regarding clinical outcomes, a statistically significant improvement was observed in the comparison between the preand 30-day postoperative VAS and ODI scores, with no significant difference in relation to sex. No peri- or postoperative complications were observed. All patients successfully completed surgery and were discharged after recovery from anesthesia. Conclusion: There was a significant improvement in pain and functional status 30 days after percutaneous endoscopic discectomy performed to correct lumbar disc herniation, with no difference in relation to sex. In addition, no peri- or postoperative complications were observed. Future studies, with longer follow-up times, comparing clinical outcomes from the various techniques of percutaneous endoscopic discectomy are necessary. Level of evidence III; Retrospective comparative study.
\end{abstract}

Keywords: Diskectomy, Percutaneous; Spine; Low Back Pain.

\section{RESUMO}

Objetivos: Avaliar a intensidade da dor e o estado funcional antes da cirurgia e em 30 dias de pós-operatório de discectomia endoscópica lombar percutânea. Métodos: Estudo de coorte retrospectivo. Foram incluídos pacientes tratados com discectomia endoscópica percutânea, de janeiro de 2019 a outubro de 2020, no complexo hospitalar Irmandade Santa Casa de Misericórdia de Porto Alegre. Os dados foram coletados do prontuário eletrônico dos pacientes por dois médicos independentes. Os desfechos clínicos foram avaliados pela pontuação da Escala Visual Analógica (EVA) e do Índice de Incapacidade Oswestry (ODI). Resultados: Foram incluídos 46 pacientes no estudo, com média de idade de 52,6 \pm 15,8 anos, sendo 27 (58,7\%), do sexo masculino. Quanto aos desfechos clínicos, observou-se melhora estatisticamente significativa com relação às escalas de EVA e ODI na comparação entre pré-operatório e 30 dias depois da cirurgia, sem diferença significativa com relação ao sexo. Não foram obsenadas complicações peri e pós-operatórias. Todos os pacientes completaram a cirurgia com sucesso e receberam alta após recuperação da anestesia. Conclusão: Observou-se melhora significativa da dor e do estado funcional 30 dias depois da discectomia endoscópica percutânea realizada para correção da hérnia de disco lombar, sem diferença com relação ao sexo. Além disso, não foram observadas complicações peri e pós-operatórias, assim como não houve necessidade de internação hospitalar. Futuros estudos, com maior tempo de seguimento, que comparem os desfechos clínicos através das diversas técnicas de discectomia endoscópica percutânea fazem-se necessários. Nível de evidência III; Estudo retrospectivo comparativo

Descritores: Discotomia Percutânea; Coluna Vertebral; Dor Lombar.

\section{RESUMEN}

Objetivo: Evaluar la intensidad del dolor y el estado funcional antes de la cirugía y 30 días después de la discectomía endoscópica lumbar percutánea. Métodos: Estudio de cohorte retrospectivo. Se incluyeron pacientes tratados mediante discectomía endoscópica percutánea, de enero de 2019 a octubre de 2020, en el complejo hospitalario Hermandad Santa Casa de Misericordia de Porto Alegre. Los datos fueron recolectados de los registros médicos electrónicos de los pacientes por dos médicos independientes. Los resultados clínicos se evaluaron mediante la puntuación de la Escala Visual Analógica (EVA) y del Índice de Discapacidad de Oswestry (ODI). Resultados: Se incluyeron 46 pacientes en el estudio, con una edad promedio de 52, $6 \pm 15,8$ años, de los cuales 27 (58,7\%) eran del sexo masculino. En cuanto a

Study conducted at the Complexo Hospitalar Santa Casa de Porto Alegre. Porto Alegre, RS, Brazil.

Correspondence: Rosalino Guareschi Junior. Rua Casemiro de Abreu, 1785, apartamento 601, cep 99420-001, Porto Alegre, RS, Brasil. jrguareschi@gmail.com 
los resultados clínicos, hubo una mejoría estadísticamente significativa en relación a las escalas EVA y ODI al comparar el preoperatorio y 30 días después de la cirugía sin diferencia significativa en cuanto al sexo. No se observaron complicaciones perioperatorias y postoperatorias. Todos los pacientes completaron con éxito la cirugía e fueron dados de alta después de recuperarse de la anestesia, sin casos de reingreso hospitalario. Conclusión: Hubo una mejoría significativa del dolor y del estado funcional luego de 30 días de discectomía endoscópica percutánea, realizada para corregir la hernia de disco lumbar, sin diferencias en cuanto al sexo. Además, no hubo complicaciones perioperatorias y postoperatorias, así como tampoco hubo necesidad de hospitalización. Son necesarios estudios futuros, con un período de seguimiento más largo, que comparen los resultados clínicos a través de las diferentes técnicas de discectomía endoscópica percutánea. Nivel de evidencia III; Estudio comparativo retrospectivo.

Descriptores: Discectomía Percutánea; Columna Vertebral; Dolor de la Región Lumbar.

\section{INTRODUCTION}

Lumbar disc herniation $(\mathrm{LDH})$, characterized by the displacement of the nucleus pulposus beyond the limits of the disc space, ${ }^{1}$ results in intense pain in the lumbar region and changes in the strength, reflexes, and sensitivity of these patients. ${ }^{2,3}$ In recent years, many treatment strategies have been developed to reduce the pain resulting from nerve root compression. ${ }^{4}$

Spontaneous regression is observed in most cases and conservative treatment is effective in between 85 and $90 \%$ of patients. ${ }^{5-7}$ However, many times it is preferable to treat lumbar pain with minimally invasive therapies since they are reliable and easy to apply. ${ }^{8}$ Among the surgical techniques, percutaneous endoscopic lumbar discectomy was introduced more recently and allows minimally invasive access to the spinal canal, either by transforaminal or interlaminar approach. ${ }^{9,10}$

Compared to open surgery, this technique has numerous advantages, such as reduced surgical time, less bleeding, reduced complication rates, and minimal soft tissue damage, resulting in rapid recovery and early return to work. In addition, this technique can be performed under local or epidural anesthesia, resulting in greater safety for the patient. ${ }^{11}$

Previous studies have shown that the endoscopic approach was associated with postoperative functionality and pain intensity scores similar to those of open approaches. However, the minimally invasive technique has shown significant clinical improvement and reductions in surgical time, blood loss and hospital stay compared to open approaches. ${ }^{9,12-14}$

Given the high prevalence of LDH in the world population and the repercussions on quality of life, studies that evaluate the clinical impact and functionality of individual submitted to percutaneous endoscopic lumbar discectomy are needed, especially in developing countries like Brazil.

Thus, the objective of the present study was to evaluate pain intensity and functional status in the periods prior to and 30 days following percutaneous endoscopic discectomy performed for the treatment of lumbar disc herniation.

\section{METHODS}

This study followed the standards suggested by the STROBE Statement for writing cohort articles. ${ }^{15}$

\section{Design}

Retrospective cohort study.

\section{Population}

Patients diagnosed with lumbar disc herniation and treated by percutaneous endoscopic lumbar discectomy at the Irmandade Santa Casa de Misericórdia de Porto Alegre hospital complex in the South Region of Brazil, between January 2019 and October 2020, were evaluated retrospectively.

In order to establish the diagnosis, the patients routinely are submitted to an imaging examination (magnetic resonance or computed tomography) showing the lumbar disc herniation at the level and on the side corresponding to the spinal nerve root signs and symptoms.

The exclusion criteria were as follows: 1) upper lumbar disc disease (L2/L3 or higher), 2) history of lumbar surgery, 3) anterior disc prolapse, 4) previous spine surgery, 5) spondylolisthesis, 6) greater than moderate spinal stenosis, 7) instability, and 8) pregnancy.
The data were collected from the electronic patient medical records by two independent physicians. Patients who undergo LDH surgery are routinely reevaluated in pre- and postoperative outpatient consultations, in which the questionnaires used in this study are administered.

The clinical outcomes were evaluated using the Oswestry Disability Index (ODI) and Visual Analog Scale (VAS) scores. The ODI score assesses the degree of disability in patients with spinal disorders. This score ranges from 0 to 100 , with the higher scores indicating greater pain-related disability. The VAS score ranges from 0 to 10 , where the higher the score, the greater the pain. There scores are applied routinely in the spine surgery service of the Santa Casa hospital complex, both preoperatively and 30 days after surgery.

The clinical outcomes were obtained from records of the regular outpatient visits or telephone interviews conducted by the surgical team during the one-month postoperative follow-up period and collected from the electronic medical records.

The primary outcome was evaluated from clinical results (functionality and pain) and the secondary outcome included the difference in the functionality and pain scale assessments between the sexes, as well as the description of hospitalization time (days), complications, and readmission to the hospital.

\section{Statistical analysis}

The data were analyzed using the Statistical Package for the Social Sciences, version 18.0 for Windows (SPSS Inc., Chicago, IL, USA).

Continuous variables were described as mean and standard deviation or median and interquartile interval. Categorical variables were described as absolute (number of cases) and relative (\% of all cases) frequencies.

For quantitative data with normal distribution, group differences (male and female) were evaluated using the independent sample $\mathrm{t}$ test and the differences within the groups between pre- and postoperative data were evaluated using paired sample t tests in accordance with the symmetry of the variables. The qualitative data were analyzed using the chi square test, with the Yates correction or Fisher's exact test if necessary.

All the statistical tests used were two-tailed and a level of significance of $5 \%$ was established.

\section{Ethics}

This study was conducted in accordance with the Declaration of Helsinki and approved by the Institutional Review Board of the Irmandade Santa Casa de Misericórdia de Porto Alegre (No. 4.380.117). Because this was a retrospective cohort study, the informed consent form was waived. However, all researchers signed the statement of confidentiality of the subjects and the study data.

\section{RESULTS}

Forty-six patients who underwent percutaneous endoscopic discectomy, $57 \%$ via interlaminar and $43 \%$ via transforaminal access, were evaluated. The mean age of the sample was $52.6 \pm 15.8$ years and $27(58.7 \%)$ of the individuals were male.

Figure 1 shows the surgical treatment for lumbar disc herniation by means of interlaminar approach percutaneous endoscopic lumbar discectomy. 


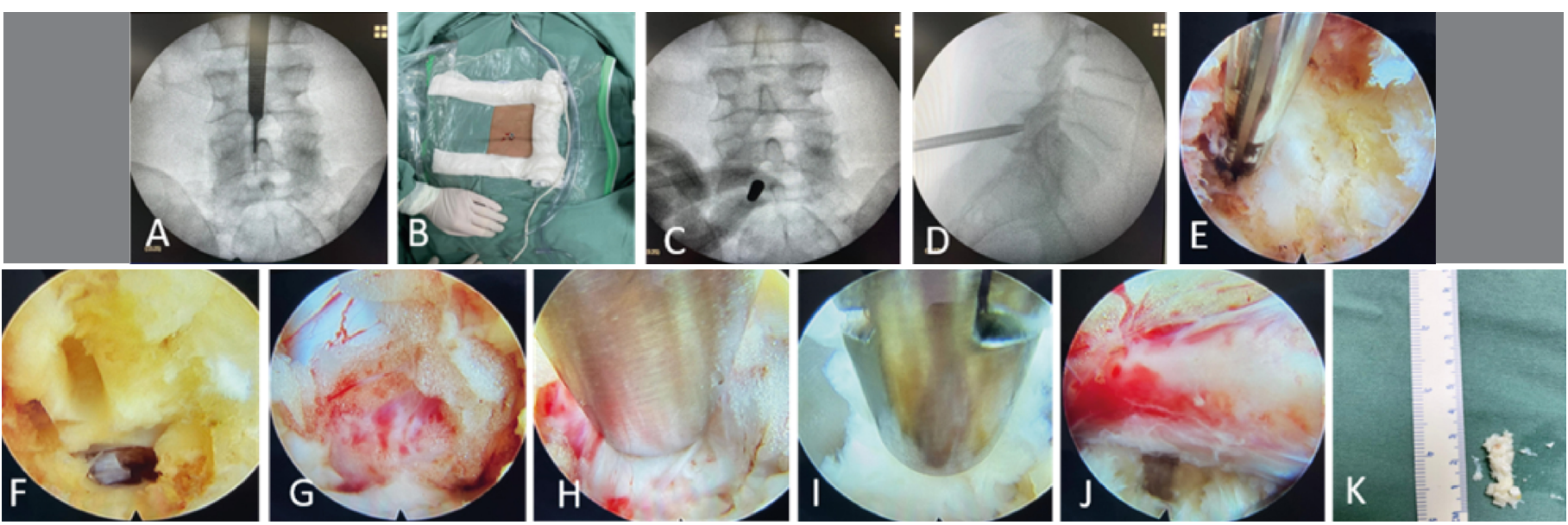

Figure 1. Male patient, 38 years of age, submitted to interlaminar approach percutaneous endoscopic lumbar discectomy. A) Marking of the entry point for interlaminar access, B) Clinical image of the interlaminar access, C and D) Confirmation of the level with radioscope assistance, E) Dissection and exposure of the yellow ligament, F) Opening of the yellow ligament for access to the spinal canal, G) Visualization of the root, $\mathrm{H}$ ) Displacement of the root for access to the herniation, I) Discectomy completed, J) View of the compression-free root following removal of the herniation, K) Herniation removed.

Statistically significant clinical improvement was observed in the comparison between the pre- and 30-day postoperative VAS and ODI scale scores (Table 1). These results were maintained when the patients were separated by sex (Table 2). Figure 2 shows the mean scores of both scales by sex.

No peri- or postoperative complications were observed. All patients successfully completed the surgery, that is, without complications, without dislocation, dural rupture, nerve root lesions, or infections. The 46 patients evaluated were discharged after anesthetic recovery, with no cases of hospital readmission. No drainage was necessary and none of the patients used analgesics, such as opioids, following the operation.

\section{DISCUSSION}

The present study, conducted with patients who underwent treatment for lumbar herniation via percutaneous endoscopic lumbar discectomy at a recognized spinal reference center in the South Region of Brazil, observed clinically significant improvement in functional status, as well as a reduction in pain intensity 30 days after surgery. There was no difference between the sexes. Additionally, the application of this technique did not generate any peri- or postoperative complications and all patients were discharged after anesthetic recovery.

Although open lumbar microdiscectomy is still considered the gold standard surgical method for LDH, percutaneous endoscopic lumbar discectomy has been in evidence over the last few years..$^{13,14,16}$ Regardless of the surgical approach, this technique stands

Table 1. Comparison of the pain intensity and functional status indicators of patients submitted to percutaneous endoscopic lumbar discectomy.

\begin{tabular}{c|c|c|c}
\hline & Pre-op & 30 days Post-op & p-value \\
\hline VAS, median (II) & $7(6-8)$ & $3(2-4)$ & $<0.001$ \\
\hline ODI, median (II) & $40(36-70)$ & $15(10-25)$ & $<0.001$ \\
\hline
\end{tabular}

VAS = Visual Analog Scale, ODI=Oswestry Disability Index, $I I=$ interquartile interval.

Table 2. Comparison by sex of the pain intensity and functional status indicators of patients submitted to percutaneous endoscopic lumbar discectomy.

\begin{tabular}{c|c|c|c}
\hline & Pre-op & 30 days Post-op & p-value \\
\hline VAS, median (II) & & & \\
\hline Male & $7(6-8)$ & $2(2-3)$ & $<0.001$ \\
\hline Female & $7(6-8)$ & $3(2-5)$ & $<0.001$ \\
\hline ODI, median (II) & & & \\
\hline Male & $40(36-70)$ & $16(10-34)$ & $<0.001$ \\
\hline Female & $46(38-74)$ & $12(10-25)$ & $<0.001$ \\
\hline
\end{tabular}

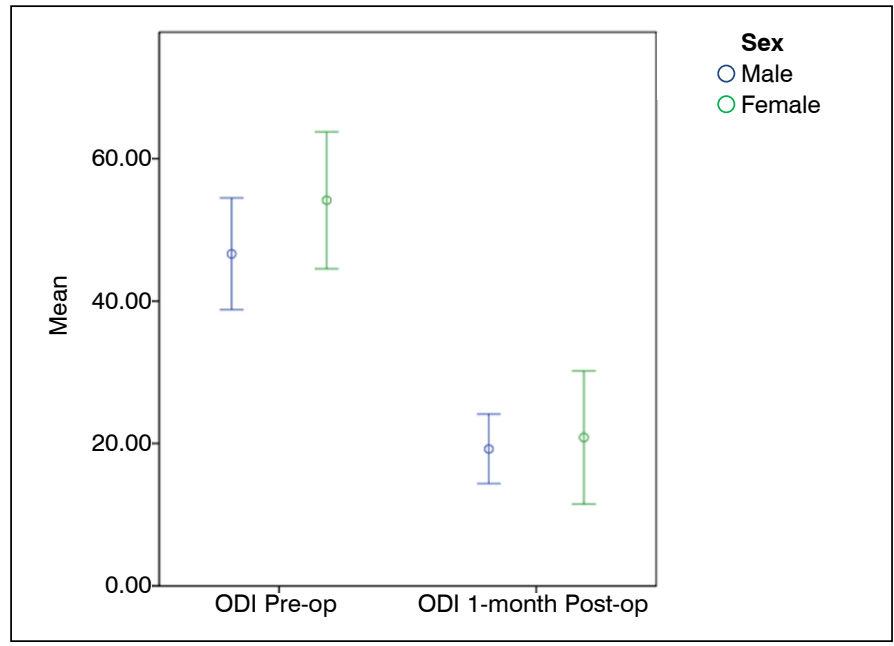

Figure 2. Mean functional status evaluated using the Oswestry Disability Index by sex.

out as a minimally invasive procedure resulting in rapid rehabilitation, minimal trauma, especially of the paravertebral muscle, as well as better preservation of the bone structures and prevention of excessive nerve root retraction. ${ }^{17-19}$

The clinical aspects evaluated in this study showed improvement both in pain intensity and functional status at 30 days after surgery, as compared to the preoperative scores. These results reflect the quality of life of the patients from a clinical perspective. Similar results were observed in other studies. ${ }^{20-23}$ However, few studies have evaluated the same follow-up period. ${ }^{20,21}$ Hua et al. reported statistically significant differences between pre- and 30-day-postoperative VAS (back pain: 6.83 and 2.08, and leg pain: 7.67 and 1.81, respectively) and ODI (30.48 and 11, respectively) scores. ${ }^{21}$ Similarly, Hua et al. observed improvement in the ODI score from 61.6 (46 to 84) to 16.3 (10 to 28 ) one month after surgery.22

Ahn et al., ${ }^{23}$ evaluated the VAS and ODI scores of 204 patients submitted to percutaneous transforaminal endoscopic discectomy over a five-year period. They reported a significant improvement in the mean VAS score from 7.64 at the beginning of the study to $1.71,0.81,0.90$ and 0.99 at six weeks, one year, two years, and five years following surgery, respectively. Similar results were found for the mean ODI score, which was $67.2 \%$ at the beginning of the study and $15.7 \%, 8.5 \%, 9.4 \%$ and $10.1 \%$ in postoperative follow-ups at six weeks, one year, two years, and five years, respectively. The patients 
presented improvements in both scores over the years, but this trend does not seem to continue after five years of follow-up.

In a meta-analysis of studies with up to two years of follow-up, the VAS scores following endoscopic discectomy were lower at three months, six months, 12 months and 24 months than those of the traditional technique (difference of $-2.20,-2.63,-0.83,-1.98$, respectively). Improvement in the ODI scores was also observed at three, 12, and 24 months following endoscopic discectomy (difference of $0.06,0.37$, and 1.60 , respectively). However, none of these changes was statistically significant at any time during follow-up. ${ }^{16}$

As regards the technique used, percutaneous endoscopic discectomy is a less invasive spine surgery technique for LDH and can reduce hospitalization time and postoperative back pain as compared to other techniques. ${ }^{24}$ In addition, this method, regardless of the approach, has proved to be more cost effective than microdiscectomy after one year of follow-up ${ }^{25}$ a relevant fact since total costs of low back pain in the United States exceed USD 100 billion per year. ${ }^{25}$ In Brazil, it also has an important impact since it is one of the main factors responsible for high rates of disability and absence from work, generating a high cost to society and, consequently, to the public health system. ${ }^{26}$

Regarding the aspects related to the surgical technique, no peri- or postoperative complications were observed in the present study. These normally include infection, spinal cord injury, cerebrospinal fluid leaks, nerve root damage and postoperative sensory abnormalities. ${ }^{12,27}$ Jhala and Mistry reported seven dural injuries, one nerve injury, and four patients with recurrence, four cases of discitis, and five facet joint removals. ${ }^{28}$ Kulkarni et al. verified $5 \%$ with dural injuries, $2.1 \%$ with residual disc herniation, $1.5 \%$ recurrence, $0.5 \%$ at the wrong level, and $0.5 \%$ with infection. ${ }^{29}$ Such complication rates are possibly due to the larger sample size and longer follow-up time of these studies.

The present work has some limitations. First, it is a retrospective cohort study, limited to routine outpatient protocols and already collected data. Second, the scales were applied at a single moment. Third, no control patients, i.e., patients treated by open lumbar discectomy or microdiscectomy, were included.

In conclusion, we observed significant improvement in pain and functional status 30 days following percutaneous endoscopic lumbar discectomy performed to correct lumbar disc herniation. Moreover, no peri- or postoperative complications were observed with the use of this technique, nor was there any need for hospitalization. Further studies, with longer follow-up times and that compare the clinical outcomes of the various percutaneous endoscopic discectomy technique are necessary.

All authors declare no potential conflict of interest related to this article.

CONTRIBUTION OF THE AUTHORS: Each author made significant individual contributions to the manuscript. RGJ and CAGC: conception of the theme, preparation of the research project, data collection, statistical analysis, writing, review and final approval of the work; GGT: data collection, active participation in the discussion of the results, review and final approval of the work; SC, FL, CDB, NRR, and FL: review, discussion of the results, writing, review, and final approval of the work; YK: conception of the theme, review, discussion of the results, revision and final approval of the work.

\section{REFERENCES}

1. Williams AL, Murtagh FR, Rothman SLG, Sze GK. Lumbar Disc Nomenclature: Version 2.0. AJMR Am J Neuroradiol [Internet]. 2014 ;35(11):2029. Available from: http://www.ajnr.org/ lookup/doi/10.3174/ajnr.A4108

2. Daghighi MH, Pouriesa M, Maleki M, Fouladi DF, Pezeshki MZ, Mazaheri Khameneh R, et al. Migration patterns of herniated disc fragments: a study on 1.020 patients with extruded lumbar disc herniation. Spine J . $2014 ; 14(9): 1970-7$. Available from: https://linkinghub. elsevier.com/retrieve/pii/S1529943013019852

3. Jordan J, Konstantinou K, O'Dowd J. Herniated Lumbar Disc. BMJ Clin Evid. 2009:2009:1118. Available from: https://thejns.org/view/journals/j-neurosurg/81/5/article-jns.1994.81.5.0806b.xml.xml

4. van Steensel S, Bloemen A, van den Hil LCL, van den Bos J, Kleinrensink GJ, Bouvy ND. Pitfalls and clinical recommendations for the primary lumbar hernia based on a systematic review of the literature. Hernia. 2019;23(1):107-71.

5. Chiu C-C, Chuang T-Y, Chang K-H, Wu C-H, Lin P-W, Hsu W-Y. The probability of spontaneous regression of lumbar herniated disc: a systematic review. Clin Rehabil. 2015;29(2):184-95. Available from: http://journals.sagepub.com/doi/10.1177/0269215514540919

6. Zhong M, Liu JT, Jiang H, Mo W, Yu PF, Li XC, et al. Incidence of spontaneous resorption of lumbar disc herniation: A meta-analysis. Pain Physician. 2017:20(1):E45-E52.

7. Lurie JD, Tosteson TD, Tosteson ANA, Zhao W, Morgan TS, Abdu WA, et al. Surgical Versus Nonoperative Treatment for Lumbar Disc Herniation. Spine (Phila Pa 1976). 2014;39(1):3-16.

8. Aydin Y, Ziyal IM, Duman H, Türkmen CS, Başak M, Sahin Y. Clinical and radiological results of lumbar microdiskectomy technique with preserving of ligamentum flavum comparing to the standard microdiskectomy technique. Surg Neurol [Internet]. $2002 ; 57(1): 5-13$; discussion 13-4. Available from: http://www.ncbi.nlm.nih.gov/pubmed/11834260

9. Sivakanthan S, Hasan S, Hofstetter C. Full-Endoscopic Lumbar Discectomy. Neurosurg Clin N Am [Internet]. $2020 ; 31$ (1):1-7. Available from: https://doi.org/10.1016/j.nec.2019.08.016

10. Gibson JNA, Cowie JG, Iprenburg M. Transforaminal endoscopic spinal surgery: The future "gold standard" for discectomy? - A review. Surgeon. 2012;10(5):290-6.

11. Ruan W, Feng F, Liu Z, Xie J, Cai L, Ping A. Comparison of percutaneous endoscopic lumbar discectomy versus open lumbar microdiscectomy for lumbar disc herniation: A meta-analysis. Int J Surg. 2016;31:86-92.

12. Ahn SS, Kim SH, Kim DW, Lee BH. Comparison of Outcomes of Percutaneous Endoscopic Lumbar Discectomy and Open Lumbar Microdiscectomy for Young Adults: A Retrospective Matched Cohort Study. World Neurosurg. 2016:86:250-8.

13. Chen $P, H u$ Y , Li Z. Percutaneous endoscopic transforaminal discectomy precedes interlaminar discectomy in the efficacy and safety for lumbar disc herniation. Biosci Rep [Internet]. 2019;39(2): BSR20181866. Available from: https://portlandpress. com/bioscirep/article/doi/10.1042/BSR20181866/110894/Percutaneous-endoscopictransforaminal-discectomy

14. Kim M, Lee S, Kim H-S, Park S, Shim S-Y, Lim D-J. A Comparison of Percutaneous Endoscopic Lumbar Discectomy and Open Lumbar Microdiscectomy for Lumbar Disc Herniation in the Korean: A Meta-Analysis. Biomed Res Int [Internet]. $2018 ; 2018$ 9073460. Available from: https://www.hindawi.com/journals/bmri/2018/9073460/

15. von Elm E, Altman DG, Egger M, Pocock SJ, Gøtzsche PC, Vandenbroucke JP. The Strength- ening the Reporting of Observational Studies in Epidemiology (STROBE) Statement: Guidelines for reporting observational studies. Int J Surg [Internet]. 2014:12(12):1495-9. Available from: https://linkinghub.elsevier.com/retrieve/pii/S174391911400212X

16. Li XC, Zhong CF, Deng G B, Liang RW, Huang CM. Full-endoscopic procedures versus traditional discectomy surgery for discectomy: A systematic review and meta-analysis of current global clinical trials. Pain Physician. 2016;19(3):103-18.

17. Yeung AT, Tsou PM. Posterolateral endoscopic excision for lumbar disc herniation: Surgical technique, outcome, and complications in 307 consecutive cases. Spine (Phila Pa 1976). 2002:27(7):722-31.

18. Choi KC, Kim JS, Park CK. Percutaneous endoscopic lumbar discectomy as an alternative to open lumbar microdiscectomy for large lumbar disc herniation. Pain Physician. 2016;19(2):E291-300.

19. Li M, Yang H, Yang Q. Full-endoscopic technique discectomy versus microendoscopic discectomy for the surgical treatment of lumbar disc herniation. Pain Physician. 2015;18(4):359-63.

20. Hua W, Zhang Y, Wu X, Gao Y, Li S, Wang K, et al. Outcomes of discectomy by using full-endoscopic visualization technique via the interlaminar and transforaminal approaches in the treatment of L5-S1 disc herniation. Medicine (Baltimore) [Internet]. 2018;97(48):e13456. Available from: http://journals.Iww.com/00005792201811300-00087

21. Song H, Hu W, Liu Z, Hao Y, Zhang X. Percutaneous endoscopic interlaminar discectomy of L5-S1 disc herniation: a comparison between intermittent endoscopy technique and full endoscopy technique. J Orthop Surg Res [Internet]. 2017;12(1):162. Available from: http://josr-online.biomedcentral.com/articles/10.1186/s13018-017-0662-4

22. Hua W, Tu J, Li S, Wu X, Zhang Y, Gao Y, et al. Full-endoscopic discectomy via the interlaminar approach for disc herniation at L4-L5 and L5-S1. Medicine (Baltimore) [lnternet]. 2018; 97(17):e0585. Available from: http://journals.Iww.com/00005792-201804270-00085

23. Ahn Y, Lee U, Kim W-K, Keum HJ. Five-year outcomes and predictive factors of transforaminal full-endoscopic lumbar discectomy. Medicine (Baltimore) [Internet]. 2018; 97(48):e13454. Available from: http://journals.Iww.com/00005792-201811300-00086

24. Choi KC, Shim HK, Hwang JS, Shin SH, Lee DC, Jung HH, et al. Comparison of Surgical Invasiveness Between Microdiscectomy and 3 Different Endoscopic Discectomy Techniques for Lumbar Disc Herniation. World Neurosurg. 2018; 116:e750-e758.

25. Choi K-C, Shim H-K, Kim J-S, Cha KH, Lee DC, Kim ER, et al. Cost-effectiveness of microdiscectomy versus endoscopic discectomy for lumbar disc herniation. Spine J. 2019;19(7):1162-69.

26. Nascimento PRC, Pena Costa LO. Prevalência da dor lombar no Brasil: Uma revisão sistemática. Cad Saúde Pública. 2015:31(6):1141-55

27. Kim M, Lee S, Kim H-S, Park S, Shim SY, Lim DJ. A Comparison of Percutaneous Endoscopic Lumbar Discectomy and Open Lumbar Microdiscectomy for Lumbar Disc Herniation in the Korean: A Meta-Analysis. BioMed Research International. 2018;2018:9073460.

28. Jhala A, Mistry M. Endoscopic lumbar discectomy: Experience of first 100 cases. Indian J Orthop. 2010; 44(2):184-90.

29. Kulkarni AG, Bassi A, Dhruv A. Microendoscopic lumbar discectomy: Technique and results of 188 cases. Indian J Orthop. 2014;48(1):81-7. 